\title{
ACCESS TO JUSTICE IN EASTERN EUROPE
}

\author{
Founded by East European Law Research Center
}

\begin{abstract}
AJEE is an English-language journal which covers issues related to access to justice and the right to a fair and impartial trial. AJEE focuses specifically on law in East European countries, such as Ukraine, Poland, Lithuania, and other countries of the region, sharing in the evolution of their legal traditions. While preserving the high academic standards of scholarly research, AJEE allows its contributing authors, especially young legal professionals and practitioners, to present their articles on the most current issues.
\end{abstract}

Editor in Chief

Deputy

Editor in Chief

Editorial Board

Advisory Board

Managing Editors

Language Editors Assistant Editor
Dr. Sc. (Law) Iryna Izarova, Kyiv, Ukraine

Prof. Elisabetta Silvestri, JD, LLM (Cornell) (Law), Pavia, Italy

Prof. Dr. Alan Uzelac, Head of the Procedural Law Department, Faculty of Law, University of Zagreb, Croatia

Prof.Dr. Cornelis Hendrik(Remco) Van Rhee, Professor ofEuropean Legal HistoryandComparative Civil Procedure, Department of Foundations and Methods of Law, Faculty of Law, Maastricht University, the Netherlands

Prof. Dr. Vytautas Nekrosius, Head of the Private Law Department, Faculty of Law, Vilnius University, Lithuania

Dr. Vigita Vebraite, PhD (Law), Assoc. Prof. of the Private Law Department, Faculty of Law, Vilnius University, Lithuania

Prof. Dr. Dr. h.c. (Law) Alexander Trunk, Director of the Institute of East European Law, Chairman of Center of East European Studies of Christian-Albrecht University of Kiel, Germany Prof.habil. Dr. RadoslawFlejszar, Head of the Civil Procedure Department, Jagiellonian University, Poland Dr. habil. Tadeusz Zembrzuski, Prof. of the Civil Procedure Department, Warsaw University, Poland Dr. Bartosz Szolc-Nartowski, PhD (Law), Assoc. Prof., University of Gdańsk, Poland

Costas Popotas, LLM QUB, Head of the Unit, Directorate-General for Administration, Court of Justice, Luxembourg

Dr. Henriette-Cristine Boscheinen-Duursma, Priv.-Doz., Dr, LLM (Passau), MAS (European Law), Law Faculty, University of Salzburg, Austria

Prof. Dr. Federico Bueno de Mata, Prof. of the Procedural Law Department, Law Faculty, Salamanca University, Spain

Prof. habil. Dr. Vassilios Christianos, Prof. Emeritus of European Union Law, Faculty of Law, University of Athens, Greece

Dr. Gabriel M. Lentner, Assoc. Prof. of International Law and Arbitration, Department of Law and International Relations at Danube University Krems, Lecturer in Law, Faculty of Law, University of Vienna, Austria

Dr. Fernando Gascón-Inchausti, Prof. of the Department of Procedural and Criminal Law, Universidad Complutense de Madrid Law School, Spain

Dr. Prof. Laura Ervo, Head of Unit, The Örebro University, Sweden

Dr.Sc. (Law), Prof. Ivan Grytsenko, Prof. of the Administrative Law Department, Institute of Law, Taras Shevchenko National Board University of Kyiv, Ukraine

Dr.Sc. (Law), Prof. Anatoliy Getman, Rector of the YaroslavMudryi NationalLaw University, Ukraine Dr. habil. Robert Kulski, Prof. of the Civil Procedure Department II, Łódź University, Poland Prof. Dr.Sc. (Law) Yurii Prytyka, Prof. of the Civil Procedure Department, Institute of Law, Taras Shevchenko National University of Kyiv, Ukraine

Dr.Sc. (Law) Serhij Venediktov, Prof. of the Labour Law Department, Institute of Law, Taras Shevchenko National University of Kyiv, Ukraine

Dr. Yuliia Baklazhenko, $\mathrm{PhD}$ (Pedagogy), MA in Translation, Assoc. Prof. at the National Technical University of Ukraine 'Igor Sikorsky Kyiv Polytechnic Institute', Ukraine

Dr. Serhij Kravtsov, PhD (Law), Assoc. Prof. at the Civil Procedure Department, Yaroslav Mudryi National Law University, Ukraine

David Phelan and Sarah White

Mag. Polina Siedova, Master in Law, Yaroslav Mudryi National Law University, Ukraine

For further information on our activities and services, please visit our website http://ajee-journal.com

To submit your manuscript, please follow the instructions in our Guide. Papers and abstracts should be submitted online to one of the following email addresses: info@ajee-journal.com, editor@ajee-journal.com, assistant@ajee-journal.com

(C) AJEE, 2021

ISSN 2663-0575

EELRC

Publishing House VD 'Dakor' 


\title{
Access to Justice in Eastern Europe
}

\author{
Issue 1 (9) March 2021
}

\section{TABLE OF CONTENTS}

\section{Editor-in-Chief's Note}

About the Special Issue on the Occasion of the 70th Anniversary

of the European Convention on Human Rights

https://doi.org/10.33327/AJEE-18-4.1-n000043

\section{Special Note}

Victor Muraviov and Nataliia Mushak

Legal Issues of the Implementation of the Convention for the Protection of Human Rights and Fundamental Freedoms 1950 in Ukraine

https://doi.org/10.33327/AJEE-18-4.1-n000044

\section{Research Articles}

Marcin Dziurda, Agnieszka Gołąb, Tadeusz Zembrzuski

European Convention for the Protection of Human Rights and Fundamental Freedoms: Impact on Polish Law Development https://doi.org/10.33327/AJEE-18-4.1-a000045

Tatjana Zoroska-Kamilovska

Effective Remedy for Excessive Length of Proceedings:

A Macedonian Perspective

https://doi.org/10.33327/AJEE-18-4.1-a000046

Vyacheslav Komarov and Tetiana Tsuvina

The Impact of the ECHR and the Case-law of the ECtHR on Civil Procedure in Ukraine

https://doi.org/10.33327/AJEE-18-4.1-a000047

Oksana Kaplina and Anush Tumanyants

ECtHR Decisions That Influenced the Criminal Procedure of Ukraine https://doi.org/10.33327/AJEE-18-4.1-a000048 
Olena Boryslavska

Judicial Reforms in Eastern Europe: Ensuring the Right to a Fair Trial or an Attack on the Independence of the Judiciary?

https://doi.org/10.33327/AJEE-18-4.1-a000049

Nazar Bobechko, Alona Voinarovych and Volodymyr Fihurskyi

Referring a Case to the Highest Division of the Supreme Court in the Criminal Procedure Legislation of Ukraine and European Countries

https://doi.org/10.33327/AJEE-18-4.1-a000050

Iryna Sakharuk

The Protection of the Worker`s Right to Freedom of Association: the ECtHR Case-Law

https://doi.org/10.33327/AJEE-18-4.1-a000051

\section{Reforms Forum}

Maryna Stefanchuk, Oleksandr Hladun and Ruslan Stefanchuk

The Right of Access to a Court in Ukraine in the Light of the Requirements of the Convention on Protection Human Rights and Fundamental Freedoms

https://doi.org/10.33327/AJEE-18-4.1-n000052

\section{Case Notes}

Natalia Sakara

The Applicability of the Right to a Fair Trial in Civil Proceedings:

The Experience in Ukraine

https://doi.org/10.33327/AJEE-18-4.1-n000053

Yana Sandul and Andriy Strelnykov

The Impact of the Human Rights Convention on the Development of the Administrative Judiciary of Ukraine

https://doi.org/10.33327/AJEE-18-4.1-n000054

\section{Special Note}

Yuliia Baklazhenko

Ukrainian-English Translation of Legal Terms: Case Study

of Insignificant Cases and Small Claims

https://doi.org/10.33327/AJEE-18-4.1-n000055 


\title{
ABOUT THE SPECIAL ISSUE ON THE OCCASION OF THE 70TH ANNIVERSARY OF THE EUROPEAN CONVENTION ON HUMAN RIGHTS
}

\begin{abstract}
his AJEE issue begins with a special note written by Victor Muraviov and Nataliia Mushak about the ratification of the Convention in 1997 and its implementation in Ukraine. In particular, the authors draw attention to essential issues related to the implementation of the Convention in Ukraine and the concept of 'judicial precedent' since judicial practice is more traditional for Ukraine's legal system, as well as the most influential ECtHR decisions against Ukraine. The authors make some concluding remarks about the reality of human rights protection in Ukraine and provide a relevant internal policy that may be useful for further legal research.
\end{abstract}

There are seven contributors to the main research articles in this issue. In the first article, readers may find original research results prepared by Marcin Dziurda, Agnieszka Gołab, and Tadeusz Zembrzuski, the main focus of which is the impact of the Convention of the Polish Law Development. In particular, issues of the institutional and procedural components of the right to a fair trial were deeply studied.

One of the most difficult points of the trial is the reasonable length of the procedure, which has been under the scholarly spotlight for centuries. In the article written by Tatjana ZoroskaKamilovska, the right to an effective remedy is linked to a reasonable length of a trial, and the author answers the question of whether this legal remedy exists in Northern Macedonia.

A few research articles in this issue are devoted to the Ukrainian experience of applying the Convention. In particular, Vyacheslav Komarov and Tetiana Tsuvina deeply analysed the impact of the case-law of the ECtHR on Ukrainian civil procedure development. Specific attention was drawn to the impact of pilot judgments on the legal instruments, as well as the specific circumstances of the review of the case after the ECtHR decision and the procedure for providing advisory opinions of the ECtHR. The positive influence of the rule of law principle in civil procedural legislation was considered grounds for a new approach of the Supreme Court - the opposite f a purely dogmatic interpretation of the law and excessive formalism, which should be assessed as highly positive.

In Oksana Kaplina and Anush Tumanyants' article, the impact of the Convention on Ukrainian criminal procedure was studied. The achievements of the human rights evolution in Ukraine since its independence have made significant progress, specifically in criminal procedure, which had been adopted and influenced by one of the most authoritarian states half a century ago and was not in line with the very idea of human rights. The authors provided a thorough analysis and incisive opinions on the development of the criminal procedure reforms in Ukraine from the first steps to the final achievements.

The next research article focused on the independence of the judiciary in Eastern Europe as a prerequisite of the right to a fair trial. Although procedural issues have been the primary focus of research thus far, the organisation and functioning of the judiciary is the key point for implementing access to justice. The judicial reforms in Ukraine were deeply analysed by Olena Boryslavska from 
the perspectives of the constitutional states and European models of constitutionalism, and her conclusions are worth attention and useful for various groups, especially legislators.

Some interesting issues were found in the study of Nazar Bobechko, Alona Voinarovych, and Volodymyr Fihurskyi, whose attention was drawn to the procedure of referring a criminal case to the highest division of the Supreme Court with the aim of maintaining unified court practice in criminal proceedings. Comparative analyses of other European states' legislation gave the authors solid grounds for conclusions that contribute to the national doctrine, as well as to facilitating unity in court practice.

The European Convention does not only impact procedural law in Ukraine; therefore, we welcome the contribution of Iryna Sakharuk on the right of protection, which was substantially influenced by the Convention.

A few notes have been added to this issue due to their relevance to the Convention's anniversary. In particular, the note related to the current law reforms in the field of the right to a fair trial was written by Maryna Stefanchuk, Oleksandr Hladun and Ruslan Stefanchuk.

In her case note, Natalia Sakara argued for the implementation of Art. 6 in a triad of proceedings: 'disputable', 'conditionally disputable', and 'indisputable. The widely used caselaw of the ECtHR gave her grounds to contribute to the discussion of the right to a fair trial.

Specific attention was drawn to the administrative, procedural development in Ukraine under the Convention and ECtHR practice in Yana Sandul and Andriy Strelnykov's note, in which our audience may read about these interesting issues.

Legal translation is a highly requested area of scholarly research. Current projects show us the difficulties of single understandings of legal texts, and the interpretation of legal terms is a particularly interesting and important issue. In the special note written by Yuliia Baklazhenko, readers may find the results of studies related to the terms 'small claims' and 'insignificant cases', which were recently introduced in Ukrainian legislation. Instead of using highly popular and widely recognised terms for cases with low values, it was necessary to determine a more accurate term in the legislation of Ukraine and related procedure. The author's method of resolving this is worth attention and useful for comparative research.

In the last part of my note, let me kindly draw your attention to our cover, where we have tried to illustrate the sense of the Convention and its role in civil society evolution during the last seven decades. Art gives us additional tools to feel rather than think about some essential issues of everyday life since artists always open new horizons and discover new aspects of humanity before they are conceptualised or even sketched up. Even though our cover uses a piece of art created by Pete Mondrian a century ago, the piece was a counterpoint of a new stage - unified art without national boundaries. The Convention became Mondrian's point for legal development and harmonisation, especially in Eastern Europe, where traditional approaches were and are very powerful.

Following this new direction, Mondrian wanted to 'denaturalize' art, to move from natural forms to pure abstraction, which would unite different visions of the same phenomena of the surrounding world. The main tools for the image are lines filled with primary colours. Likewise, the provisions of the Convention have incorporated basic human rights, moving away from those differences that have formed in the law of different states over the past centuries. Simplifying the forms and making them ascetic and pointless, the artist achieved understanding without the subjective, as he himself later wrote: 'Neoplasticism asserts justice, because the equality of plastic tools in a composition shows that everyone can be equal among equals.'

1 The new art - the new life: The collected writings of Piet Mondrian, ed. and trans. Harry Holtzman and Martin S James (GK Hall, 1986). 
Minimalist in its essence, the article on the right of every person to a fair trial gave impetus to the development of common principles both in the organisation of courts and in the procedure of a trial of Member states, ensuring access to justice for all.

Mondrian's influence on world culture is widely recognised and limitless - it goes beyond the visual arts and art in general and has become one of the starting points for globalist trends. Today, we are surrounded by reflections on Mondrian's theme, from website design to architecture. Paraphrasing his message about the new art of a new life and applying it to our main theme, we can only add 'a new law'.

Art is a harbinger of all the significant changes that occur in society. Artists and musicians transform new needs accumulated in society through the prism of their consciousness and create new visions of the future. Artists do not see the world around us objectively, but as a kaleidoscope of subjective reflections of our society, a mix of its illnesses and successes. Before Mondrian, art was replete with the traditional clichés prevailing in the visual arts. However, a hundred years ago, he was one of the first to single out a point that gave a reference to a whole direction - a vision of the world around us, common for all regardless of cultural and national characteristics, a universal and harmonious approach to depicting the reality around us. After him, Italian or Dutch painting was no longer relevant since universalism became an immanent feature of contemporary art. The soil of a modern artist is the whole world - he is a part of a single human society, and not a particular part of it, painted with national colours.

The approach introduced by the General Declaration and the European Convention is unique - whatever the law of the Member States, everyone is guaranteed the rights enshrined in these documents. These are rights that unite all people and not ones that divide national and ethnic attitudes and traditions. Few projects are so difficult to unify as the implementation of the right to a fair trial. ${ }^{2}$

In each country, even within each jurisdiction, different approaches have been formed that are seemingly impossible to resolve at first glance. Yet, the Convention gave us a clear example, in which common views prevail over national characteristics and even shape them.

Last, we are happy to announce that professor Anatoliy Getman is joining AJEE Editorial Board as a new member. We greatly welcome our team leading scholars and professionals who contribute to the high academic standards of scholarly research and help us to develop a journal!

As usual, I would like to express my endless gratitude to all my team who help to go through the whole publishing process - to communicate with our authors, to assist in peer review, to facilitate editing, proofreading and correcting the final versions, all together we make a great job! Thanks to our authors, who trust us in publishing, our reviewers for their professional attention and help, our Editorial Board members for their support.

\section{Editor in Chief}

\section{Dr. Iryna Izarova}

Institute of Law, Taras Shevchenko National University of Kyiv, Ukraine

Managing Editor

Dr. Serhij Kravtsov,

Yaroslav Mudryi National Law University, Kharkiv, Ukraine

2 Model European Rules of Civil Procedure (with the International Institute for the Unification of Private Law, UNIDROIT) <https:/www.europeanlawinstitute.eu/projects-publications/completed-projects-old/ completed-projects-sync/civil-procedure/> accessed 18 February 2021. On the role of Convention in the harmonisation of judiciary law in Europe, see M Storme, A single civil procedure for Europe: A cathedral builders'dream <http://www.ritsumei.ac.jp/acd/cg/law/lex/rlr22/STORME.pdf> accessed 18 February 2021. 